\title{
SELF CONCEPT OF AIDS POSITIVE \& NEGATIVE TRIBAL AND NON TRIBAL WOMEN
}

\author{
Ankit P. Patel*
}

\begin{abstract}
The presents study was held in area of PANCHMAHAL district. Aim of the study is to measure the difference of AIDS positive \& negative tribal and non tribal women, about self concept. 80 women were selected randomly from Godhra' Civil hospital and Local area. In which 20 tribal and 20 non tribal from AIDS positive and tribal and 20 non tribal AIDS negative women. For present study "MENTALHEALTH BATTERY" (MHB) of Arunkumar Singh and Alpna Sen Gupta was used. From this battery only 15 items were selected (related to self concept) for the research.

For this comparison's t test was used. Result is that there is a no significant difference in self concept of women.
\end{abstract}

\section{Keyword}

The present study about self concept of women - 40 AIDS positive women - 40 AIDS negative women Total 80 women selected randomly from PANCHMAHAL district - For present research MHB test was used - $\mathrm{t}$ test apply for comparison.

*MA, Dept. of Psychology, SARDAR PATEL University, Vallabh VidhyaNagar

(C) www.ijip.in 


\section{Introduction}

The present study deals with self concept of Aids positive and negative women. Psychologists Carl Rogers and Abraham Maslow were the first to establish the notion of self-concept. According to Rogers, everyone strives to reach an "ideal self". Rogers also hypothesized that psychologically healthy people actively move away from roles created by others' expectations, and instead look within themselves for validation. On the other hand, neurotic people have "self-concepts that do not match their experiences...They are afraid to accept their own experiences as valid, so they distort them, either to protect themselves or to win approval from others.[2]"

The self-categorization theory developed by John Turner states that the self-concept consists of at least two "levels": a personal identity and a social one. In other words, one's self-evaluation relies on self-perceptions and how others perceive them. Self-concept can alternate rapidly between the personal and social identity. Children and adolescents begin integrating social identity into their own self-concept in elementary school by assessing their position among peers. By age 5, acceptance from peers has a significant impact on children's self-concept, affecting their behavior and academic success [7].

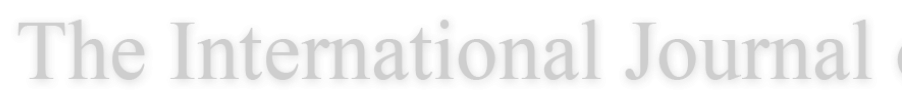

\section{HIV AIDS and Women}

Human immunodeficiency virus infection / acquired immunodeficiency syndrome (HIV/AIDS) is a disease of the human immune system caused by infection with human immunodeficiency virus (HIV). During the initial infection, a person may experience a brief period of influenza-like illness. This is typically followed by a prolonged period without symptoms. As the illness progresses, it interferes more and more with the immune system, making the person much more likely to get infections, including opportunistic infections and tumors that do not usually affect people who have working immune systems. HIV is transmitted primarily via unprotected sexual intercourse (including anal and even oral sex), contaminated blood transfusions, hypodermic needles, and from mother to child during pregnancy, delivery, or breastfeeding. Some bodily fluids, such as saliva and tears, do not transmit HIV. Prevention of HIV infection, primarily through safe sex and needle-exchange programs, is a key strategy to control the spread of the disease. There is no cure or vaccine; however, antiretroviral treatment can slow the course of the disease and may lead to a near-normal life expectancy. While antiretroviral treatment reduces the risk of death and complications from the disease, these medications are expensive and may be associated with side effects.

Summary: Women also experience HIV associated gynecologic problems many of which occur in uninfected women but with less frequency or severity.

(c) www.ijip.in 
Document Detail: Around the world, women now make up half of all people living with HIV, the human immunodeficiency virus (im-myoo-no-duh-fish-in-see), and AIDS, acquired immunodeficiency syndrome.

In the U.S., more than 25 percent of new infections are in women. Women of color are especially impacted by the disease. HIV/AIDS is the leading cause of death for African American women aged 25 to 34 .

Although most of the cases reported early in the epidemic were men, it was not long before AIDS in women was identified. Women contracted the disease primarily by sex with bisexual men or infected drug-using men or through sharing contaminated needles with infected injection drug users (IDUs). The proportion of all AIDS cases that were women and adolescent girls (aged $>13$ years) increased from $8 \%$ in 1986 to $26 \%$ in 2001.

The first symptoms of HIV infection are very much the same in men and women, although they may be more pronounced in women. They are similar to those of other acute viral illnesses: fever, joint pain, muscle ache, diarrhea, vomiting and lymphadenopathy. Weight loss, sore throat, rash and oral ulcers are also common [3].

\section{Women also experience HIV-associated gynecologic problems, many of which occur in uninfected women but with less frequency or severity.}

Vaginal yeast infections, common and easily treated in most women, often are particularly persistent and difficult to treat in HIV-infected women. Other vaginal infections may occur more frequently and with greater severity in HIV-infected women, including bacterial vaginosis and common STIs such as gonorrhea, 3 hlamydia, and trichomoniasis.

Severe herpes simplex virus ulcerations, which are sometimes unresponsive to therapy with the standard drug acyclovir, can severely compromise a woman's quality of life. Idiopathic genital ulcers, with no evidence of an infectious organism or cancerous cells in the lesion, are a unique manifestation of HIV infection.

HIV infections, which cause genital warts and can lead to cervical cancer, occur more frequently in HIV-infected women. A precancerous condition associated with HPV, called cervical dysplasia, is also more common and more severe in HIV-infected women and more apt to recur after treatment. PID appears to be more common and more aggressive in HIV-infected women than in uninfected women. Menstrual irregularities frequently are reported by HIV-infected women too.

Women whose HIV infections are detected early and receive appropriate treatment survive as long as HIV-infected men. Although several studies have shown HIV-infected women to have shorter survival times than men, this may be because women are less likely than men to be diagnosed early [8].

In an analysis of several studies involving more than 4,500 people with HIV infection, women were 33 percent more likely than men to die within the study period. The investigators could not definitively identify the reasons for excess mortality among women in this study, but they

(C) www.ijip.in 
speculated that poorer access to or use of health care resources among HIV-infected women as compared to men, domestic violence, homelessness, and lack of social supports may have been important factors.

\section{Review of literature}

Research from 1997, inspired by the differences in self-concept across cultures, suggested that men tend to be more independent, while women tend to be more interdependent. A study from 1999 showed that, while men and women do not differ in terms of independence or interdependence, they differ in their types of interdependence. Women utilize relational interdependence (identifying more with one-to-one relationships or small cliques), while men utilize collective interdependence (defining themselves within the contexts of large groups).

Gender differences in interdependent environments appear in early childhood: by age 3, boys and girls choose same-sex play partners, maintaining their preferences until late elementary school. Boys and girls become involved in different social interactions and relationships. Girls tend to prefer one-on-one (dyadic) interaction, forming tight, intimate bonds, while boys prefer group activities. One study in particular found that boys performed almost twice as well in groups than in pairs, whereas girls did not show such a difference [5].

Girls are more likely to wait their turn to speak, agree with others, and acknowledge the contributions of others. Boys, on the other hand, build larger group relationships based on shared interests and activities. Boys are more likely to threaten, boast, and call names, suggesting the importance of dominance and hierarchy in groups of male friends. In mixed-sex pairs, girls were more likely to passively watch a male partner play, and boys were more likely to be unresponsive to what their female partners were saying. The social characteristics of boys and girls tend to carry over later in life as they become men and women [6].

\section{$\underline{\text { Objectives }}$}

1. Main aim of this study is to know about the AIDS positive and negative women' self concept regarding their mental health.

2. To study and compare the self concept of AIDS positive tribal and non tribal women.

3. To study and compare the self concept of AIDS negative tribal and non tribal women.

4. To study self concept of AIDS positive and negative women from tribal group.

5. To study self concept of AIDS positive and negative women from non tribal group.

6. To know the difference between self concept of tribal and non tribal women. 
7. Massage to whole society that all aids positive women patients require more sympathy, co-operation, attention, love and care.

\section{Variable}

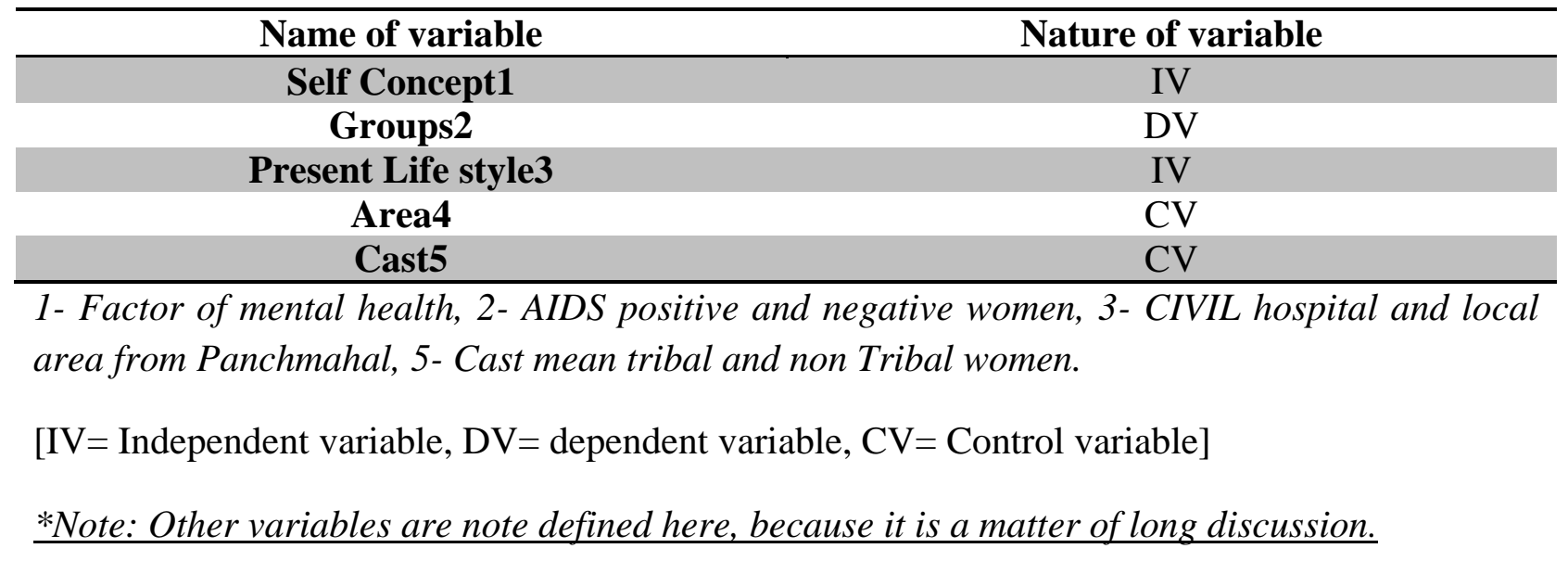

\section{Sampling}

\begin{tabular}{|c|c|c|c|c|}
\hline & \multicolumn{3}{|c|}{ *Sample of the study tin } & \\
\hline Area & Cast & Sub total & Groups & Total \\
\hline \multirow[t]{2}{*}{ Civil hospital } & Tribal women & 20 & \multirow[t]{2}{*}{ APW } & \multirow[t]{2}{*}{40} \\
\hline & $\begin{array}{l}\text { Non Tribal } \\
\text { women }\end{array}$ & 20 & & \\
\hline \multirow[t]{2}{*}{ Local aria } & Tribal women & 20 & \multirow[t]{2}{*}{ ANW } & \multirow[t]{2}{*}{40} \\
\hline & $\begin{array}{l}\text { Non Tribal } \\
\text { women }\end{array}$ & 20 & & \\
\hline Total & -- & 80 & -- & 80 \\
\hline
\end{tabular}

* The sample for the study compression of 80 women of AIDS positive and negative residing in Panchmahal district.

\section{Research design}

For present study "MENTALHEALTH BATTERY" (MHB) of Arunkumar Singh and Alpna Sen Gupta was used. From this battery only 15 items were selected (related to self concept) for the research [1].

80 women selected randomly from Panchmahal district area. In this research two groups selected, (1) APW (AIDS Positive Women) and (2) ANW (AIDS Negative Women). In which 20 tribal and 20 non tribal women are from APW group and 20 tribal and 20 non tribal women

(c) www.ijip.in 
are from ANW group. Thus data of 80 women was collected from godhra' civil hospital and Local area.

After that according to MHB analysis was done. $t$ test was apply for all sample.

\section{Result and Interpretation}

Present study is to define self concept of AIDS positive and negative tribal and non tribal women in Panchmahal, Guj. Following tables clearly indicts self concept of women. Table wise discussion is also done here.

Table no. 1; AIDS positive Women (Tribal and non Tribal)

\begin{tabular}{|c|c|c|c|c|c|c|}
\hline Groups & $\mathbf{N}$ & Mean & SD & SEM & t & Level \\
\hline Tribal & 20 & 6.50 & 2.52 & 0.56 & \multirow[t]{2}{*}{0.2735} & \multirow{2}{*}{\begin{tabular}{|l|} 
NS \\
0.01
\end{tabular}} \\
\hline Non Tribal & 20 & 6.30 & 2.08 & 0.47 & & \\
\hline
\end{tabular}

There is no difference in self concept of AIDS positive women. Why? The common cause is there, life media, internet, better education, counseling, level of dictation, etc.

Table no. 2; AIDS negative Women (Tribal and non Tribal)

\begin{tabular}{|l|l|l|l|l|l|l|}
\hline \multicolumn{1}{|c|}{ Groups } & \multicolumn{1}{|c|}{ N } & \multicolumn{1}{c|}{ Mean } & \multicolumn{1}{c|}{ SD } & \multicolumn{1}{c|}{ SEM } & t & \multicolumn{1}{c|}{ Level } \\
\hline Tribal & 20 & 6.80 & 2.50 & 0.56 & 1.0281 & NS \\
\cline { 1 - 3 } Non Tribal & 20 & 7.65 & 2.72 & 0.61 & & 0.01 \\
\hline
\end{tabular}

This table indicates equal level of self concept in both the groups. There is no any difference in between opposite cast, means this research is with the society and mordent generation that AIDS negative tribal and non tribal women are similar in all manner.

Table no. 3; AIDS positive and negative Women (Tribal)

\begin{tabular}{|l|l|l|l|l|l|l|}
\hline Groups & \multicolumn{1}{|c|}{ N } & \multicolumn{1}{c|}{ Mean } & \multicolumn{1}{c|}{ SD } & SEM & t & \multicolumn{1}{c|}{ Level } \\
\cline { 1 - 5 } APW & 20 & 6.50 & 2.52 & 0.56 & 0.3773 & NS \\
\cline { 1 - 2 } & 20 & 6.80 & 2.50 & 0.56 & & 0.01 \\
\hline
\end{tabular}

All the AIDS positive and negative tribal women of Panchmahal district have the same type of self concept, which is mention in this table. 
Table no. 4; AIDS positive and negative Women (non Tribal)

\begin{tabular}{|l|l|l|l|l|l|l|}
\hline \multicolumn{1}{|c|}{ Groups } & \multicolumn{1}{|c|}{ N } & \multicolumn{1}{|c|}{ Mean } & \multicolumn{1}{c|}{ SD } & \multicolumn{1}{|c|}{ SEM } & \multicolumn{1}{c|}{ t } & \multicolumn{1}{|c|}{ Level } \\
\hline APW & 20 & 6.30 & 2.08 & 0.47 & 1.7633 & NS \\
ANW & 20 & 7.65 & 2.72 & 0.67 & & 0.01 \\
\hline
\end{tabular}

AIDS positive and negative non tribal women of Panchmahal district area have similar self concept. These all reality show in particular table.

Table no. 5; AIDS positive and negative Women (all over)

\begin{tabular}{|l|l|l|l|l|l|l|}
\hline \multicolumn{1}{|c|}{ Groups } & \multicolumn{1}{|c|}{ N } & \multicolumn{1}{c|}{ Mean } & \multicolumn{1}{c|}{ SD } & \multicolumn{1}{c|}{ SEM } & \multicolumn{1}{c|}{ Level } \\
\cline { 1 - 2 } & 40 & 6.40 & 2.28 & 0.36 & 1.5021 & $\mathrm{NS}$ \\
\cline { 1 - 2 } & 40 & 7.23 & 2.62 & 0.41 & & 0.05 \\
\hline
\end{tabular}

Analysis of this table is also not significant difference. Women of AIDS positive and AIDS negative are similar in self concept.

Table no. 6; Tribal and non Tribal women (all over)

\begin{tabular}{|l|l|l|l|l|l|l|}
\hline \multicolumn{1}{|c|}{ Groups } & \multicolumn{1}{|c|}{ N } & \multicolumn{1}{|c|}{ Mean } & \multicolumn{1}{c|}{ SD } & \multicolumn{1}{|c|}{ SEM } & \multicolumn{1}{|c|}{ Level } \\
\hline Tribal & 40. & 6.65 & 2.49 & 0.39 & 0.5846 & NS \\
\hline Non Tribal & 40 & 6.98 & 2.49 & 0.39 & & 0.05 \\
\hline
\end{tabular}

Table six means that tribal and non tribal women have the equal self concept level.

\section{Conclusions}

1. There is no significant difference on self concept of aids positive tribal and non tribal women.

2. There is no significant difference on self concept of aids negative tribal and non tribal women.

3. There is no significant difference on self concept of aids positive and negative tribal women.

4. There is no significant difference on self concept of aids positive and negative non tribal women.

5. There is no significant difference on self concept of aids positive and negative women.

6. There is no significant difference on self concept of tribal and non tribal women. 


\section{Significance of research}

This research work is successful, because everywhere in the Gujarat, the government has introduced batter education, batter counseling, and batter medical services in every areas of Gujarat state. All the government policy is linked with each other by many academic, cultural and many foundation programs.

Due to this kind of similar self concept in Panchmahal district areas are equal.

\section{Suggestions}

- A research project many be undertaken to compare mental health factors of aids positive and negative male and female.

- A similar study can be done with the student of engineering and medical students.

- A similar study can be performed on international basis.

- Self concept can be measured by many other Indian areas, religious, etc.

- I request the whole society to behave in good manner with all aids positive persons.

\section{References}

1. Arunkumar singh and Alpna Sen Gupta, "MHB", National Psychological Corporation, 2005

2. Jhon Hattie, "Self Concept", Erlbaum, New York, 1992

3. K. Jhon, "Project of Mission is to Chang the Course of this HIV/AIDS Pandemic though a unique and comprehensive focus on Women", http://www.thewellproject/org, 2005

4. Linda Tschirhart Sanford, Mary Ellen Donovan, "Women and Self Concept", Penguin Books, 1984

5. Mervin D. Lynch, Ardyth A. Norm, Kenneth J. Gergen, "Self Concept: Advances in Theory and Research", Ballinger Publishing, New York, 1981

6. Ruth. C. Wylie, "The Self Concept: A Critical Survey of Pertinent Research Literature", University of Nebraska Press, 1962

7. Wikipedia, www.en.wikipedia.org/self-concept.html, 2014 


\section{Charts}

Chart no. 1; AIDS positive Women (Tribal and non Tribal)

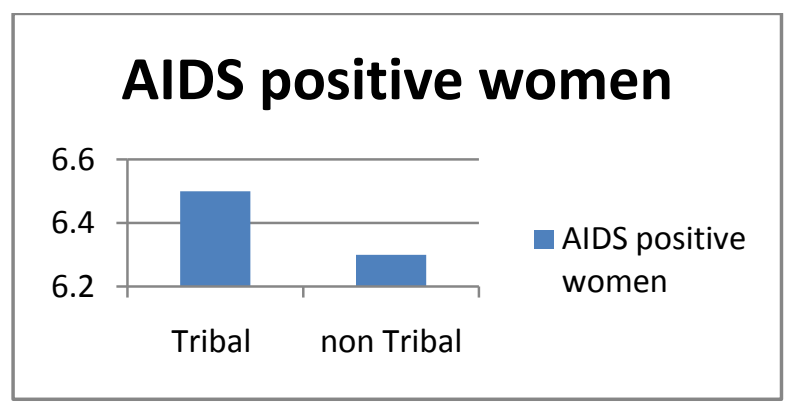

Chart no. 2; AIDS negative Women (Tribal and non Tribal)

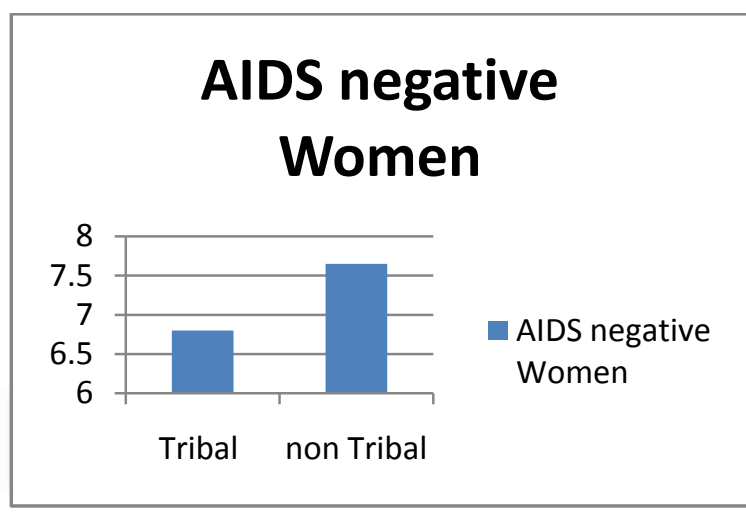

Chart no. 3; AIDS positive and negative Women (Tribal)

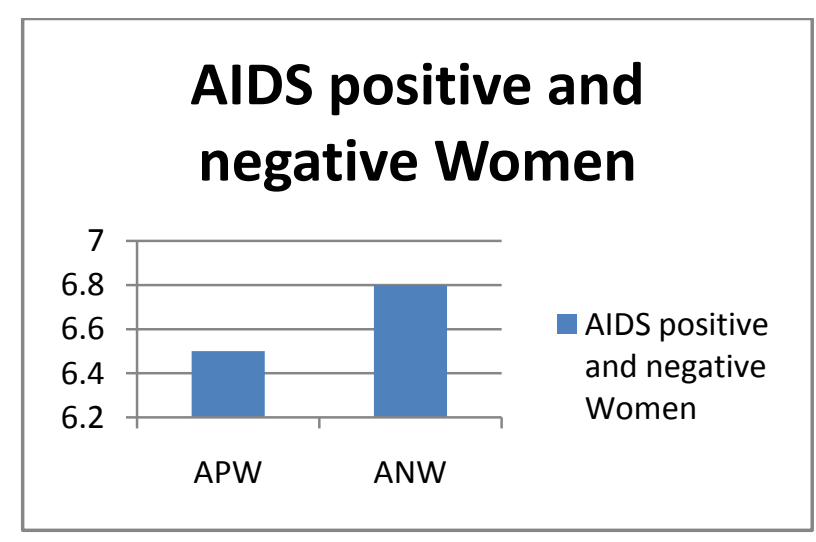

(c) www.ijip.in 
Chart no. 4; AIDS positive and negative Women (non Tribal)

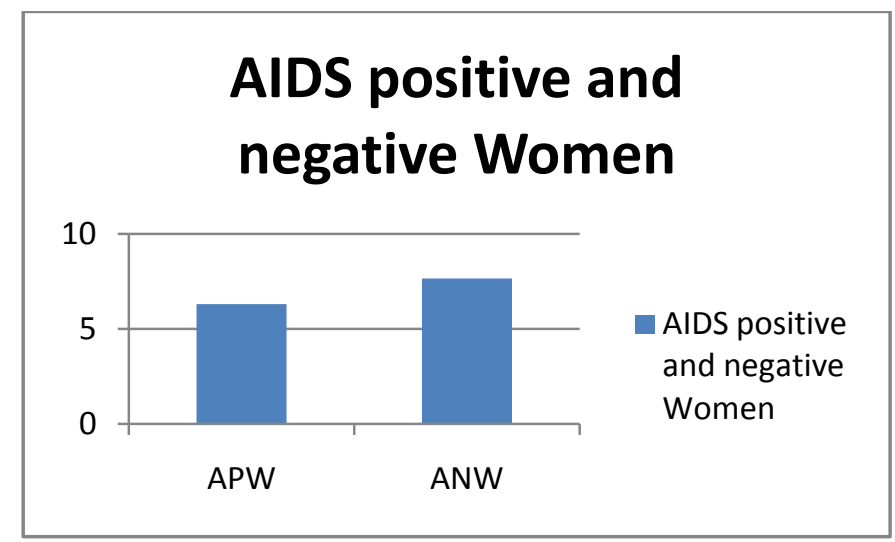

Chart no. 5; AIDS positive and negative Women (all over)

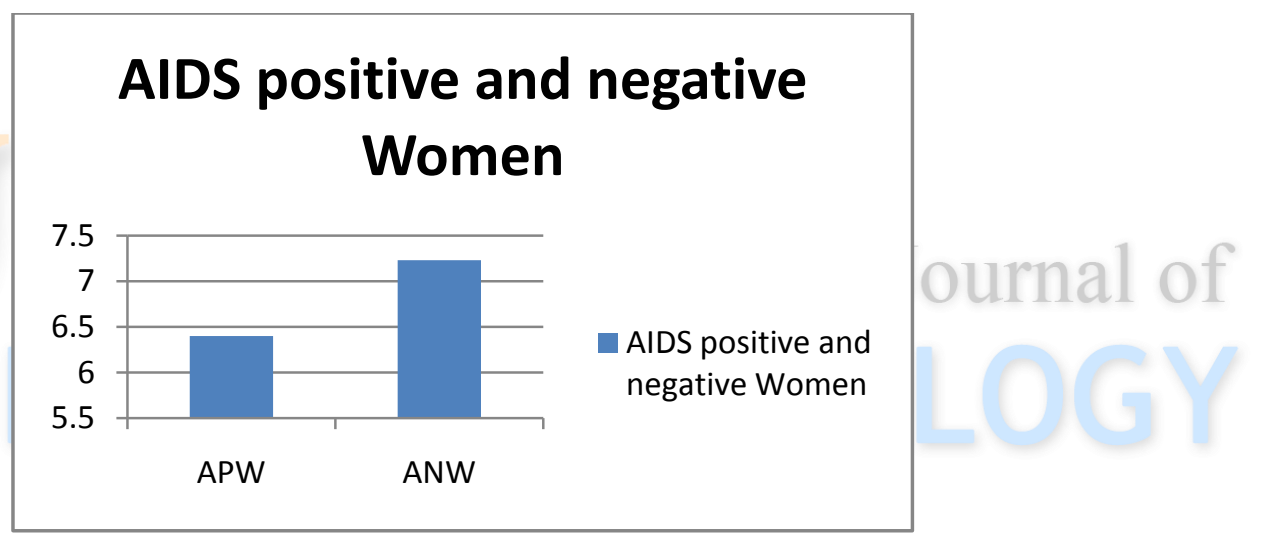

Chart no. 6; Tribal and non Tribal women (all over)

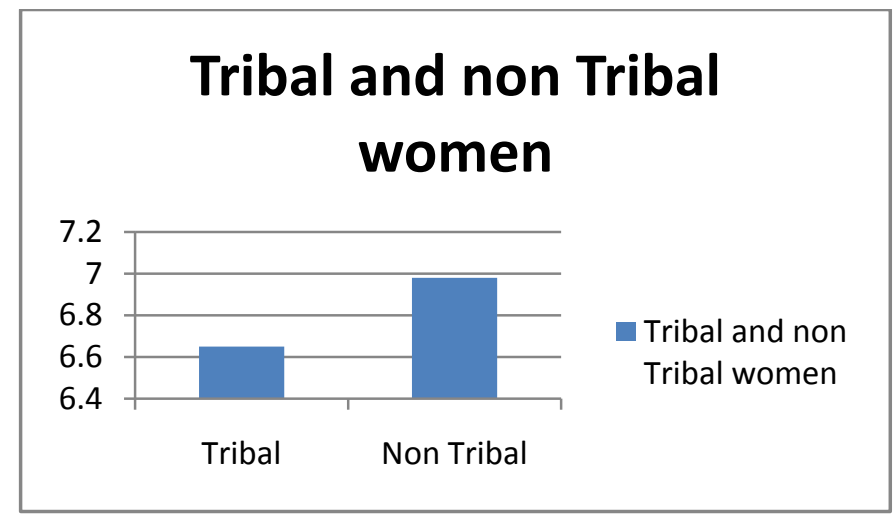

(c) www.ijip.in 